\title{
THE ROLE OF ENTREPRENEURIAL ORIENTATIONS IN TALENT RETENTION AMONGST MALAYSIAN ENGINEERS
}

\author{
IDRIS OSMAN \\ FAUZIAH NOORDIN \\ IDAYA HUSNA MOHD \\ KOE WEI LOON \\ Faculty of Business and Management \\ Universiti Teknologi Mara
}

\begin{abstract}
This paper examined the linkage between entrepreneurial orientation (EO) and talent retention amongst Malaysian engineers from the perspective of the entrepreneurial orientation theory. A cross-sectional survey of 104 engineers from private organisations in Malaysia was conducted to test the hypothesised relationships between the constructs. The population comprised graduate and professional engineers who were registered under the Board of Engineers Malaysia (BEM). The purposive sampling method was employed for data analysis purposes. Data was analysed using the partial least square-structural equation modelling technique. The results of this study indicated a significant relationship between innovativeness, proactiveness, risk-taking and competitive aggressiveness, and the intention to stay (ITS). Autonomy was found not significant in predicting engineers' ITS in the same jobs. Engineers require EO to support their freedom of ideas and thoughts to exploit opportunities, produce creativity, and solve engineering task-related problems and uncertain situations. EO dimensions can be used to predict engineers' ITS in current employments. This study provides crucial information for organisations and policy-makers to develop mechanisms and policies to enhance engineers' involvement of effective EO for increasing retention behaviours and career satisfaction. As the EO of engineers' increase, the ITS will also increase.
\end{abstract}

Keywords: Engineers, entrepreneurial orientation, intention to stay, talent, Malaysia. 


\section{Introduction}

Over thirty years ago, studies relating to behaviours, attitudes and traits had become a central issue underlying engineers' complex behaviours and attitudes, career orientations, and employee shortages in the engineering sector (Abdull Rahman, 2012; Igbaria \& Siegel, 1992; Igbaria, Kassicieh, \& Silver, 1999; Kharbanda, \& Stallworthy, 1990; and Williamson, Lounsbury, \& Han, 2013). Attention was given to engineers' perceiving their engineering paths to be meaningful career experiences, and how core entrepreneurial orientation (EO) components influenced their career expectations, job performance and job satisfaction. EO requires an engineer to optimise powerful technical knowledge and skills to develop capabilities and competencies to an extent that he or she can be an independent expert to solve engineering and non-engineering task-related problems. Engineering requirements are created and used to determine engineers' career orientations (e.g. technical, managerial role, entrepreneurial, project and hybrid orientation), as all these components determine the greater work values for engineers (Alavi, Moteabbed, \& Arasti, 2012). Evidence suggests that engineers' EO is a crucial component in entrepreneurial process, successful entrepreneurial organisations and decisions to remain in one's job tenure (Menzel, Aaltio, \& Ulijn, 2007; Tremblay, Wils, \& Proulx, 2002; Yang, Ma, \& Hu, 2011).

It is believed that the use of EO is likely to resolve the quitting behaviours of engineers to move to another job. If an organisation knows how to control the engineers' EO within an organisation, low job performance, and turnover behaviours can be avoided (Lee, 1994). In the literature, organisations employed EO for measuring performance, growth and productivity (Antoncic \& Antoncic, 2011; Entebang, Harrison, \& Run, 2010; Jia, Wang, Yu, 2014). However, Kollman, Christofor and Kuckertz (2007) argued that a successful entrepreneurial organisation gains from an individual's participation in EO processes and activities. The impact of technology has influenced organisations to consider certain types of individual behaviours and attitudes for successful EO (Grip \& Smits, 2012; Menzel, et al., 2007; Oyedele, 2010). Relying on individual behaviours and attitudes, in some characteristics, supports the power of key individuals recognising the competitive business demands (e.g., technology amd skills) and optimising organisational resources. In creating inhouse EO, engineers apply freedom to innovate things and cultivate proactive solutions to solve uncertainties in task-related problems. In addition, engineers employ a high degree of autonomy to control 
engineering task-related problems and participate in decision-making processes (Kharbanda et al., 1990; Igbaria, et al., 1992; Tremblay, et al., 2002; Williamson et al., 2013).

Serious involvement of organisations in the engineers' EO would deal with a clear path of the engineers turning towards positive behavioural intentions. Critical questions have vigorously challenged many scholars to overlook adapting $\mathrm{EO}$ within an organisational area to predict intention to stay (ITS) amongst engineers. A logical prediction of how employee shortages can be controlled by organisations is by connecting engineers' behaviours with their employment expectations. As mentioned earlier, if an engineer applies for EO, it possibly has a significant implication on his or her ITS in his or her current employment. Previous conceptual studies, qualitative and empirical research have clearly acknowledged the research gaps between the influence of EO and individuals' (e.g. entrepreneurs, students and teachers) entrepreneurial intentions and job performance (Bolton \& Lane, 2012; Elenurm, 2012; Kollman et al., 2007; $\mathrm{Wu}, 2009)$. From a theoretical gap, too, the EO theory has not clearly defined and expended the use of $\mathrm{EO}$ for predicting individual behavioural intentions. Despite the importance of managing engineers' behaviours and attitudes, no attention has been paid to the role of EO from an individual analysis in predicting engineers' ITS. Being limited only to EO from an individual level (e.g. engineer) and its influence on ITS, hence, study was aimed at investigating the influence of EO (e.g. innovativeness, proactiveness, risk-taking, autonomy and competitive aggressiveness) on ITS amongst Malaysian engineers in private organisations.

\section{Literature Review}

Talent can be defined as a person who has high skills, knowledge and expertise in producing and innovating ideas (Festing \& Scha"fer, 2014). He or she can be an excellent performer and a valuable asset to help organisations lead with core competencies (Dries, 2013; Hiltrop, 1999). Talent exists in a rare, unique and exceptional form, and talent cannot be imitated (Collings \& Mellahi, 2009; Govaerts, Kyndt, Dochy, \& Baert, 2011; Guidice, Heames, \& Wang, 2009; Udo, Guimãrães, \& Igbaria, 1997). From an organisational level, talent retention is one of the crucial talent management activities and it has received critical attention to retain talents (Gelens, Dries, Hofmans, \& Pepermans, 2013; Lewis \& Heckman, 2006; Zhang \& Bright, 2012). Talent retention 
is defined as a process of encouraging talented individuals to remain with the same employment (Gangrade, Dubey, \& Chouhan, 2014; Sahi \& Mahajan, 2014). The term talented individual can be referred to as a key individual's characteristics and traits, namely high expertise, specialised skills, innovativeness and creativity (Abdull Rahman, 2012; Alavi et al., 2012; Igbaria et al., 1992; Williamson et al., 2013). Talent characteristics assist many scholars to describe engineers as talented workers. A talented engineer is a key component in the workforce in the nation, and he or she has wide knowledge, skill and expertise in his or her field (Abdull Rahman, 2012; Igbaria et al., 1992; Williamson et al., 2013).

It is essential to note that an engineer obtains a high level of autonomy, creativity and innovation, and has a strong determination in his or her career paths. Often, in an emerging knowledge economy, engineers are called professional workers and knowledge workers (Abdull Rahman, 2012; George, 2015). One of the greatest challenges is that organisations continuously hide engineers' talents and creativity in producing innovative activities and product development (Menzel et al., 2007; Tremblay et al., 2002). The adverse impact of separating talent and creativity affects engineers' determination for career satisfaction and turnover behaviours towards current employments in a short period (Williamson et al., 2013). Loosing talented engineers will lead an organisation to suffer from investing huge costs for replacing new entrants. Despite being costly, importing a new entrant has a number of limitation potentials. First, organisations might spend a long time to expect the same level of performance from the new entrants compared to the leavers, and second, a huge gap of performance might exist between the expected and the actual performance.

\section{Intention to Stay}

As Chang and Chang (2008) state, "intention is a special thing or action with a special attitude or means, purpose, or plan in the individual heart". Intention to stay (ITS) refers to an employee's consciousness and willingness to stay in the same job and organisation on a longterm basis (Tett \& Meyer, 1993). It has been considered as the best predictor of the actual turnover behaviour of an employee. There is a strong possibility that using ITS for predicting the actual behavioural intentions will estimate almost 99 percent of employees who will permanently continue with their intention to stay with the same employment (Price \& Mueller, 1981). Previous research comparing ITS and turnover intentions (e.g. intention to leave) has found that the antecedents used for turnover intentions are probably not significant in 
increasing ITS amongst employees. Research has consistently shown that ITS lacks usage in predicting positive behavioural intentions. Consequently, a huge sum of money should be spent to recruit new employees for replacement if one of the existing employees leaves his or her current job. Throughout this study, the term ITS will refer to an engineer's willingness to stay with his or her current employment.

\section{Extending the EO theory to Individual Talent Retention}

Theorising entrepreneurial behaviours within organisations can be explained and generated from the EO theory. EO relates to an organisation's strategic orientation which concerns entrepreneurial aspects such as decision-making styles, processes, practices and methods (Lumpkin \& Dess, 1996). An early study of Covin and Slevin (1986) argued that entrepreneurship has become an essential feature of a high-performance organisation. Risk-taking, innovativeness and proactiveness are the main features, and each feature is linked to an organisation's willingness to take high-risk projects, be bold and aggressive in exploiting opportunities, and initiating actions to which competitors respond. To lead in the competitive marketplace, Lumpkin et al. (1996) argued that additional components of EO such as autonomy and competitive aggressiveness complete the EO for a new business entry to perform well in a dynamic business environment. Wise EO components such as innovativeness, proactiveness, risktaking, autonomy and competitive aggressiveness can be employed as a successful strategy if a new entry integrates these behaviours with environmental factors (e.g. dynamic, munificence, complexity and industry characteristics) and organisational factors (e.g. size, structure, strategy, strategy-making process, firm resources, culture and top management team characteristics).

In an analysis of EO, Davis, Bell, Payne and Kreiser (2010); Entebang et al. (2010); Jia et al. (2014); Khalili, Nejadhussein, and Fazel (2013); and Kropp, Lindsay, and Shoham (2006) found that innovativeness, proactiveness, autonomy, risk-taking and competitive aggressiveness have positive and significant relationships with organisational performance, growth and productivity. With a flexible function of $\mathrm{EO}$, other researchers measured EO components in predicting an individual's entrepreneurial intention and job performance, for example, Bolton et al. (2012); Elenurm (2012); Kollman et al. (2007); and Wu (2009). Preliminary work on EO from an individual analysis was undertaken by (Kollman et al., 2007). They showed that EO constructs can be transferred to measure individual performance. In their 
discussions of EO from an individual analysis, the efforts to develop an entrepreneur within an organisation must take into consideration cultural, political and legal environments, and macro and micro economy factors. A few scholars now argue that theorising in-house EO through the EO theory will drive the intended consequences of individual entrepreneurial intentions, job performance and career satisfaction (Bolton et al., 2012; Kollman et al., 2007; Williamson et al., 2013). This present study postulates that transferring EO into engineers' entrepreneurial behaviours will increase ITS and career satisfaction in their current employment. In the present report, the definitions of EO dimensions used for the study were taken from Lumpkin et al. (1996); Rauch, Wiklund, Lumpkin, and Frese (2009) as shown in Table 1.

Table 1

EO Dimensions

\begin{tabular}{ll}
\hline \multicolumn{1}{c}{ Dimensions } & \multicolumn{1}{c}{ Definitions } \\
\hline Innovativeness & $\begin{array}{l}\text { Tendency to engage in and support new } \\
\text { ideas, novelty, experimentation and creative } \\
\text { processes that may result in new products, } \\
\text { services or technological processes. }\end{array}$ \\
Proactiveness & $\begin{array}{l}\text { Tendency to lead rather than follow in } \\
\text { the development of new procedures and } \\
\text { technologies, and introduction of new products } \\
\text { or services. }\end{array}$ \\
Risk-taking & $\begin{array}{l}\text { Tendency to undertake risky projects and } \\
\text { management preferences for acting boldly in } \\
\text { order to achieve organizational objectives. }\end{array}$ \\
Autonomy & $\begin{array}{l}\text { Independent action of an individual or a team } \\
\text { bringing forth an idea or a vision and carrying } \\
\text { it through to competition. }\end{array}$ \\
Competitive & $\begin{array}{l}\text { Propensity to directly and intensively challenge } \\
\text { its competitors to achieve entry or improve } \\
\text { position to outperform industry rivals in the } \\
\text { marketplace }\end{array}$ \\
\hline
\end{tabular}




\section{The Relationships between EO and ITS amongst Engineers}

Increasing $\mathrm{EO}$ activities from within is likely to control the internal mobility of key employees from leaving recent organisations ( $\mathrm{Yi}$, Sheu, \& Zhi, 2009). There is the potential limitation of decreasing EO affecting an engineer's interest to continue his or her career with the same employment. To develop engineers as intrapreneurs, the organisation must encourage EO for engineers to secure their career potentials and ways to innovate and create new ideas and thoughts. It is believed that EO is an important element for engineers' career satisfaction and positive behavioural intentions (e.g. ITS) within an organisation. This section explains further the relationships between EO and ITS from an individual analysis. Figure 1 shows the research model of the current study.

\section{Innovativeness and ITS}

Innovativeness is defined as willingness to support creativity, experimentation and creative activities in producing new products, servicesandnew technology(Lumpkinetal.,1996).Fromanindividual's perspective, innovative behaviours pursue an individual's ability to explore new opportunities creatively (Bolton et al., 2012). Kollman et al. (2007) claimed that an individual's attitude towards innovation is an important determinant for EO. Innovation lets individuals have the ability to pursue new opportunities and creativity. Bolton et al. (2012) revealed that innovative was a dominant element of EO. The results of the collections showed that 1,102 students' innovative behaviours were positively correlated with entrepreneurial propensity at $0.36^{* *}$. $\mathrm{Wu}$ (2009) examined EO amongst 337 college students in Nanjing, China, and there was a positive and significant relationship between innovativeness and EO $(r=0.55)$. There is some evidence that innovativeness directly influences retention outcomes on individual employees. For example, Shih and Susanto (2011) studied the impact of innovative work behaviour (IWB) on turnover intentions amongst 135 Indonesian workers in manufacturing and pharmaceutical organisations. The findings revealed that IWB had a negative impact on turnover intentions $(\beta=0: 20 ; \beta<0.05)$. Engineers' innovativeness will promote ideas and strategies and transform their ideas into tangible business results (e.g. profit). Moreover, engineers need the freedom to be creative and original, and permanently involved in any innovation and changes within organisations (Alavi et al., 2012; Igbaria et al., 
1992; Kharbanda et al., 1990; Menzel et al., 2007; Williamson et al., 2013). Thus, the following hypothesis is proposed:

H1: Innovativeness is positively related to engineers' ITS.

\section{Proactiveness and ITS}

As Lumpkin et al. (1996) states: "proactiveness refers to an opportunityseeking, forward-looking perspective which involves the introduction of new products or services ahead of competition and acting in anticipation of future demand". Strategies to enhance individual proactive behaviour are related to taking a chance, proactively implementing and solving ideas, and innovation. Griffin, Neal, and Parker (2007) added that the advantages of being a proactive individual is that, he or she identifies efficient work methods, suggests ways to improve the work team, and participates in many projects to improve an entrepreneurial organisation's practices and activities. Investigating the proactive behaviour and behavioural intentions of engineers has received limited attention. In the literature, the influence of proactive behaviour connects with innovative work behaviour. Proactive behaviours capture the engineers' creativity in solving routine and non-routine engineering-related problems (Campbell, Gluesing, \& Perelli, 2012; Menzel et al., 2007; Williamson et al., 2013). Proactiveness enhances the engineers' ability to think conceptually. Difficulties arise when modern organisations are not engaged with proactive behaviours, as a result, effective individual performance (e.g. turnover) cannot be guaranteed (Crant, 2000). Bolton et al. (2012) and Wu (2009) shared common thoughts of how proactiveness affects individuals' entrepreneurial intentions. Association between proactiveness and individual behavioural intentions (entrepreneurship) will help individuals recognise more opportunities and avoid unwanted employment problems. The higher the proactive behaviours of individuals (e.g. engineers), the less likely engineers will leave their current employment. Hence, we propose that:

H2: Proactiveness will positively relate to engineers' ITS.

\section{Risk-taking and ITS}

Risk-taking refers to the tendency to take bold actions into unknown new markets, committing a large portion of resources to ventures with uncertain outcomes (Lumpkin et al., 1996). Risk-taking exists in different situations, namely venturing into the unknown, heavy 
borrowing and committing large amounts of corporate assets in uncertain environments. A number of researchers have characterised risk-taking into several forms. These include: operations that are generally seen as involving high risks; strong inclination towards high-risk projects; maintaining preference for acting to achieve organisational objectives; maintaining a bold, aggressive posture to maximise the probability of exploiting potential opportunities; taking financial risks require that the organisation to obtain large loans in order to grow; taking personal risks; and embracing risk-taking behaviour that involves major financial commitments to achieve high returns by grabbing opportunities. Risk-taking behaviour assumes individual risks and willingness to make commitments (Bolton et al., 2012). A consequence of implementing risk-taking behaviour is shaping engineers' abilities to predict uncertain situations and taskrelated problems that can lead to higher satisfaction and ITS (Igbaria et al., 1992). Despite this, engineers tend to solve daily technical problems using their conscious and sub-conscious mental systems to create interesting and enjoyable environments (Campbell et al., 2012; Kharbanda et al., 1990). Assigning interesting tasks has positively influenced engineers' job involvement and career satisfaction $(r=0.32$, $p<0.01)$, and has negatively correlated with the intention to leave $(r=-$ $0.30, p<0.01)$ (Igbaria et al., 1992). Hence, based on the literature, it is hypothesised that:

\section{H3: A higher level of risk-taking by engineers will lead to higher ITS.}

\section{Autonomy and ITS}

Autonomy refers to the independent action of an individual or a team bringing forth an idea or a vision and carrying it through to competition (Lumpkin et al., 1996). Autonomy empowers an individual with the freedom to make a decision and the power to control each decision he or she makes. As an entrepreneur, autonomy reflects an individual's self-managing, creativity, looking for more opportunities and being an employee champion for effective EBs within an organisation. To obtain a mutual agreement of being an entrepreneur, he or she must be able to be autonomous. Khalili et al. (2013) believes that a significant amount of autonomy affects an individual's goal achievement and the challenging nature of the job; as all these motivational factors lead to a higher level of job satisfaction. For Bolton et al. (2012) autonomy, however, has failed to predict an individual's entrepreneurial intention due to lower consistency (0.208). This result, however, does not affect other researchers' 
attempts to explore this behaviour. Surveys conducted by Hashim and Wok (2015) have reported that higher job satisfaction amongst engineers will increase if engineers participate in the organisational decision-making processes (85 percent). Opportunities to express his or her ideas in a certain organisational major decision will support engineers who have worked longer with the same employer. Job challenges, creativity, and autonomy are the main ingredients for engineers to create job satisfaction and higher intentions to remain (Udo et al., 1997). Participation by engineers in any decision-making process will make them recognise potential problems and solutions to the related engineering-tasks. Autonomy is the core of engineers' career preferences (Tremblay et al., 2002). Autonomy exerts a powerful effect on ITS through improving the EO within an organisation. Based on these arguments, it is hypothesised that:

H4: Autonomy has a positive and significant relationship with engineers' ITS.

\section{Competitive Aggressiveness and ITS}

Competitive aggressiveness is a necessary element to lead in performance over competitors. In other words, competitive aggressiveness reflects the power of a firm's effort to outperform rivals in the marketplace (Lumpkin et al., 1996). Organisations with lower competitive aggressiveness would be limited with the innovation process (e.g. searching, selecting and learning processes). Additional competitive aggressiveness in EO activities provides an organisation's willingness to be conventional to rely heavily on traditional methods to compete with other rivals. The important implication of the competitive aggressiveness definition has leveraged more attempts from scholars to relate to organisational performance, growth and productivity. For an individual's effectiveness (e.g. job performance and satisfaction), competitive aggressiveness is used for predicting individual (e.g. student) entrepreneurial intentions (Bolton et al., 2012; Elenurm, 2012; Zhang et al., 2012). However, competitive aggressiveness behaviour failed to predict individual entrepreneurial intentions (Bolton et al., 2012). Much uncertainty, however, still exists about the effect of competitive aggressiveness and its influence on ITS amongst engineers. In view of this, the next proposed hypothesis is: 
H5: Competitive aggressiveness is positively and significantly related to ITS amongst engineers.

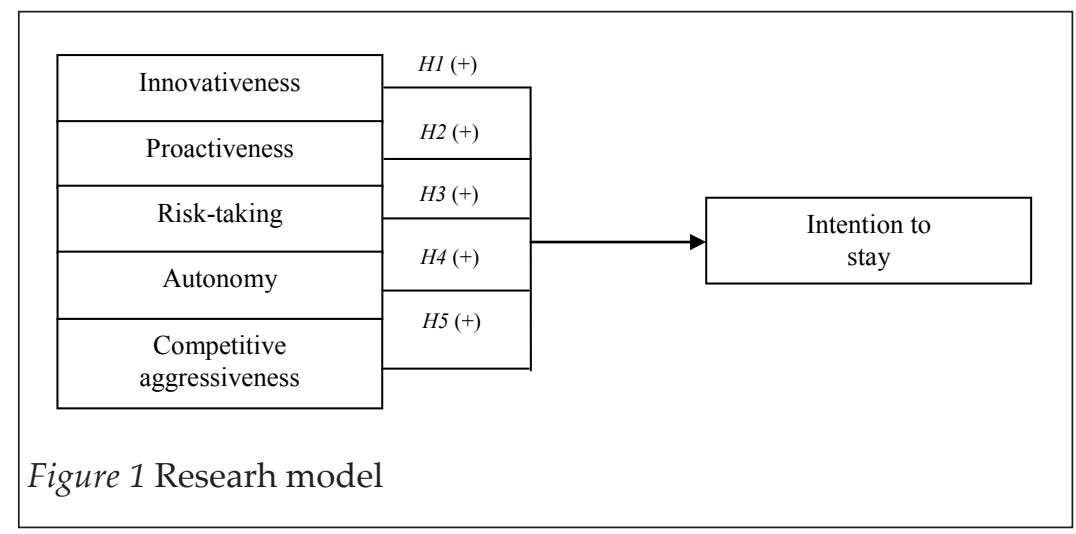

\section{Methodology}

\section{Samples and Research Procedures}

An exploratory study was designed to answer the primary objective of examining the influence of entrepreneurship on talent retention amongst engineers. The population for this study was the engineers who had registered with the Board of Engineers Malaysia (BEM). Before distributing the questionnaires, the researchers issued consent letters to the human resource (HR) representatives of the targeted private organisations to seek approval to distribute the questionnaires to their engineers. Confidentiality was ensured to the respondents and the organisations. The selection of the samples was based on the purposive sampling method, and the responses obtained were subjected to a quantitative analysis. A total of 112 responses were obtained from 300 questionnaires. From the 112, 8 were discarded and only 104 were considered for analysis. This yielded a response rate of 34.67 percent.

\section{Measures and Instruments}

The scale used to measure the items was rated on a 7-point Likert response scale ranging from 1 (strongly disagree) to 7 (strongly agree). Table 2 presents the variables and the items used for the analysis. The scales for measuring the five dimensions of entrepreneurship were derived from the EO theory. This scale consisted of innovativeness 
(seven items), proactiveness (seven items), risk-taking (six items), autonomy (four items), and competitive aggressiveness (five items). All items used were on the seven-item scale developed from previous studies (Covin et al., 1986; Lumpkin et al., 1996). Six items were used from the scale developed by Govaerts et al. (2011) to measure the ITS. Examples of items used for the EO are as follows: (a) innovativeness"My organisation has a strong intention to encourage and stimulate technological, product-market, or administrative innovation"; "My organisation engages in innovative behaviours and activities"; (b) proactiveness -"My organisation adopts creative methods of running business ahead of competitors"; "My organisation is proactive"; (c) risktaking-"My organisation commits a large portion of its resources in order to grow"; "My organisation encourages risk-taking behaviours"; (d) autonomy-"My organisation develops independent work units to enhance creative thinking"; "My organisation develops effective ways to allow employee and project team access to the needed resources to try out their new ideas"; (e) competitive aggressiveness-"My organisation adopts a price-cutting strategy to enhance a competitive position"; "My organisation routinely adopts a highly competitive, "undo-the-competitive" posture against threatening competition"; and (f) ITS- "If I wanted to do another job or function, I would look first at the possibilities within this company"; "If it were up to me, I would definitely be working for this company for the next five years".

\section{Table 2}

Variables and Instruments

\begin{tabular}{lcc}
\hline \multicolumn{1}{c}{ Variables } & Sources & Item (n) \\
\hline Innovativeness (INNO) & Covin et al. (1986); & 1-7 (7 items) \\
INNO1, INNO2, INNO3, & Lumpkin et al. & \\
INNO4, INNO5, INNO6, INNO7 & $(1996)$ & \\
Proactiveness (PROAC) & Covin et al. (1986); & 8-14 (7 items) \\
PROAC1, PROAC2, PROAC3, & Lumpkin et al. & \\
PROAC4, PROAC5, PROAC6, & $(1996)$ & \\
PROAC7 & & \\
\hline
\end{tabular}

(continued) 


\begin{tabular}{lcc}
\hline \multicolumn{1}{c}{ Variables } & Sources & Item (n) \\
\hline Risk-taking (RISK) & Covin et al. (1986); & 15-20 (6 items) \\
RISK1, RISK2, RISK3, RISK4, & Lumpkin et al. & \\
RISK5, RISK6 & $(1996)$ & \\
Autonomy (AUTO) & Covin et al. (1986); & 21-24 (4 items) \\
AUTO1, AUTO2, AUTO3, & Lumpkin et al. & \\
AUTO4 & $(1996)$ & \\
Competitive aggressiveness & Covin et al. & 25-29 (5 items) \\
(COMP) & $(1986) ;$ and & \\
COMP1, COMP2, COMP3, & Lumpkin et al. & \\
COMP4, COMP5 & $(1996)$ & \\
Intention to stay (ITS) & Govaerts et al. & 1-35 (6 items) \\
ITS1, ITS2, ITS3, ITS4, ITS5, ITS6 & $(2011)$ & \\
\hline
\end{tabular}

\section{Data Analysis Procedure}

The data were analysed using SmartPLS 3.2.6, a variance-based structural equation modelling (SEM) to test the hypotheses of the study (Hair, Hult, Ringle, \& Sarstedt, 2014). The reasons for adopting SmartPLS were: (a) capable of handling reflective and formative measures, (b) able to accommodate the small sample size, and (c) able to predict the relationships between variables. It also can simultaneously testing the two models: (a) measurement, and (b) structural model.

\section{Results}

From a total of 104, 85 participants (81.7 percent) were graduate engineers whilst 19 (18.3 percent) represented professional engineers. The total sample comprised of 85 males ( 81.7 percent) and 19 females (18.3 percent); 55.8 percent of the participants were aged between 26 and 35 years old, 57 (54.8) percent were married, and the majority of the participants were Malays ( 82 percent). The majority of the participants (83 79.8 percent) had graduate degree, 60 participants (43.3 percent) were working in Melaka and 45 (43.3 percent) of the participants had between 1 to 5 years' experience. Manufacturing firms were the highest (38.5 percent) contribution to this study. Table 3 presents the demographic profile. 
IJMS 25 (1), 105-132 (2018)

Table 3

Demographic Profile (N=104)

\begin{tabular}{|c|c|c|}
\hline Category & Frequency & Percentage \\
\hline \multicolumn{3}{|l|}{ Status of Designation } \\
\hline Graduate engineer & 85 & 81.7 \\
\hline Professional engineer & 19 & 18.3 \\
\hline \multicolumn{3}{|l|}{ Gender } \\
\hline Male & 85 & 81.7 \\
\hline Female & 19 & 18.3 \\
\hline \multicolumn{3}{|l|}{ Age } \\
\hline$<25$ years old & 9 & 8.7 \\
\hline 26-35 years old & 58 & 55.8 \\
\hline 36-45 years old & 26 & 25.0 \\
\hline $46-55$ years old & 9 & 8.7 \\
\hline > 56 years old & 2 & 1.9 \\
\hline \multicolumn{3}{|l|}{ Marital status } \\
\hline Single & 46 & 44.2 \\
\hline Married & 57 & 54.8 \\
\hline Divorced & 1 & 1.0 \\
\hline \multicolumn{3}{|l|}{ Race } \\
\hline Malay & 82 & 78.8 \\
\hline Chinese & 17 & 16.3 \\
\hline Indian & 5 & 4.8 \\
\hline \multicolumn{3}{|l|}{ Education level } \\
\hline Diploma & 16 & 15.4 \\
\hline Bachelor degree & 83 & 79.8 \\
\hline Master degree & 4 & 3.8 \\
\hline $\mathrm{PhD}$ & 1 & 1.0 \\
\hline \multicolumn{3}{|l|}{ Length of service } \\
\hline $1-5$ years & 45 & 43.3 \\
\hline $6-10$ years & 25 & 24.0 \\
\hline 11-15 years & 21 & 20.0 \\
\hline$>16$ years & 13 & 12.5 \\
\hline
\end{tabular}


IJMS 25 (1), 105-132 (2018)

\begin{tabular}{lcc}
\hline \multicolumn{1}{c}{ Category } & Frequency & Percentage \\
\hline Location & 19 & \\
\hline Johor & 4 & 18.3 \\
Kuala Lumpur & 60 & 5.8 \\
Melaka & 21 & 20.2 \\
Selangor & & \\
Specification of business & 1 & 1.0 \\
Accounting/Finance/Banking & 1 & 1.0 \\
Arts/Media/Communication & 14 & 13.5 \\
Building/Construction & 2 & 1.9 \\
Computer/IT & 13 & 12.5 \\
Electrical \& electronics & 40 & 38.5 \\
Manufacturing & 24 & 23.1 \\
Oil \& gas & 1 & 1.0 \\
Sciences & 8 & 7.7 \\
Others & &
\end{tabular}

\section{The Measurement Model}

First, we assessed internal consistency (Composite Reliability), indicator reliability, convergent validity (AVE), discriminant validity (HTMT) and multicollinearity assessment. As reported in Table 4, factor loadings of each item exceeded 0.70, ranging between 0.712 and 0.935 . It means the items used for measuring the constructs have satisfactory internal consistency reliability. For indicator reliability, items with loadings below 0.70 were removed and the items were INNO1, INNO6, RISK3, AUTO3, COMP1 and COMP5. Composite reliability for each construct ranged between 0.878 and 0.939 , and these threshold values were above 0.70 . For AVE, the values exceeded 0.50 , ranging between 0.629 and 0.755 .

Next, we assessed the discriminant validity of the scales based on HTMT, a new approach to assess the discriminant validity for variance-based SEM. This result indicated that the present study had adequate convergent validity since the value was lower than 0.85 . Table 5 presents the correlation estimates for HTMT. The results showed that the correlations between the constructs ranged between 0.611 and 0.802 , and it was indicated that the discriminant validity 
met the criteria for the HTMT assessment. For the multicollinearity assessment, the value of the Variance Inflation Factor (VIF) must be below than 0.50. Table 5 shows the VIF results where the mean values for each construct ranged between 2.243 and 3.655. Therefore, the values of VIF posited that each of the independent variables (innovativeness, proactiveness, risk-taking, autonomy, and competitive aggressiveness) did not have multicollinearity with its dependent variable (ITS). Table 4 presents the values of VIF.

Table 4

Assessment Results of The Measurement Model

\begin{tabular}{|c|c|c|c|c|}
\hline Constructs/Items & Loadings & $\mathrm{CR}$ & AVE & VIF \\
\hline Innovativeness (INNO) & & 0.939 & 0.755 & 3.655 \\
\hline INNO2 & 0.815 & & & \\
\hline INNO3 & 0.876 & & & \\
\hline INNO4 & 0.935 & & & \\
\hline INNO5 & 0.864 & & & \\
\hline INNO7 & 0.852 & & & \\
\hline Proactiveness (PROAC) & & 0.935 & 0.673 & 3.321 \\
\hline PROAC1 & 0.843 & & & \\
\hline PROAC2 & 0.799 & & & \\
\hline PROAC3 & 0.831 & & & \\
\hline PROAC4 & 0.712 & & & \\
\hline PROAC5 & 0.825 & & & \\
\hline PROAC6 & 0.870 & & & \\
\hline PROAC7 & 0.852 & & & \\
\hline Risk-taking (RISK) & & 0.900 & 0.644 & 2.647 \\
\hline RISK1 & 0.749 & & & \\
\hline RISK2 & 0.773 & & & \\
\hline RISK4 & 0.768 & & & \\
\hline RISK5 & 0.859 & & & \\
\hline RISK6 & 0.857 & & & \\
\hline Autonomy (AUTO) & & 0.879 & 0.708 & 2.243 \\
\hline AUTO1 & 0.824 & & & \\
\hline AUTO2 & 0.864 & & & \\
\hline AUTO4 & 0.836 & & & \\
\hline
\end{tabular}


IJMS 25 (1), 105-132 (2018)

\begin{tabular}{lcccc}
\hline Constructs/Items & Loadings & CR & AVE & VIF \\
\hline Competitive aggressiveness & & 0.878 & 0.706 & 2.621 \\
(COMP) & & & & \\
COMP2 & 0.784 & & & \\
COMP3 & 0.846 & & & \\
COMP4 & 0.888 & & & - \\
\hline Intention to stay (ITS) & & 0.894 & 0.629 & \\
ITS1 & 0.804 & & & \\
ITS2 & 0.716 & & & \\
ITS3 & 0.877 & & & \\
ITS4 & 0.808 & & & \\
ITS6 & 0.751 & & & \\
\hline
\end{tabular}

Table 5

Discriminant Validity (HTMT)

\begin{tabular}{lllllll}
\hline Latent constructs & AUTO & COMP & INNO & ITS & PROAC & RISK \\
\hline AUTO & & & & & & \\
COMP & 0.802 & & & & & \\
INNO & 0.762 & 0.698 & & & & \\
ITS & 0.610 & 0.461 & 0.698 & & & \\
PROAC & 0.746 & 0.692 & 0.893 & 0.645 & & \\
RISK & 0.757 & 0.890 & 0.688 & 0.609 & 0.611 & \\
\hline
\end{tabular}

Note: AUTO-Autonomy; COMP-Competitive aggressiveness; INNO-Innovativeness; ITS-Intention to stay; PROAC-Proactiveness; RISK-Risk-taking.

\section{The Structural Model}

A structural model of PLS examined each of the hypothesis to test the relationship between the constructs that operationalised as latent variables (LVs). We performed the bootstrapping with re-sampling 5000 for 104 cases to obtain the path estimates, standard errors and the t-statistics to report the significant relationships between the variables. To evaluate the structural models' explanatory power, we calculated the $R^{2}$, the amount of variance explained by the exogenous variable 
(ITQ), whilst for predictive power, we assessed path coefficient $(\beta)$, predictive relevance $\left(Q^{2}\right)$ and relative impact $\left(\mathrm{q}^{2}\right)$.

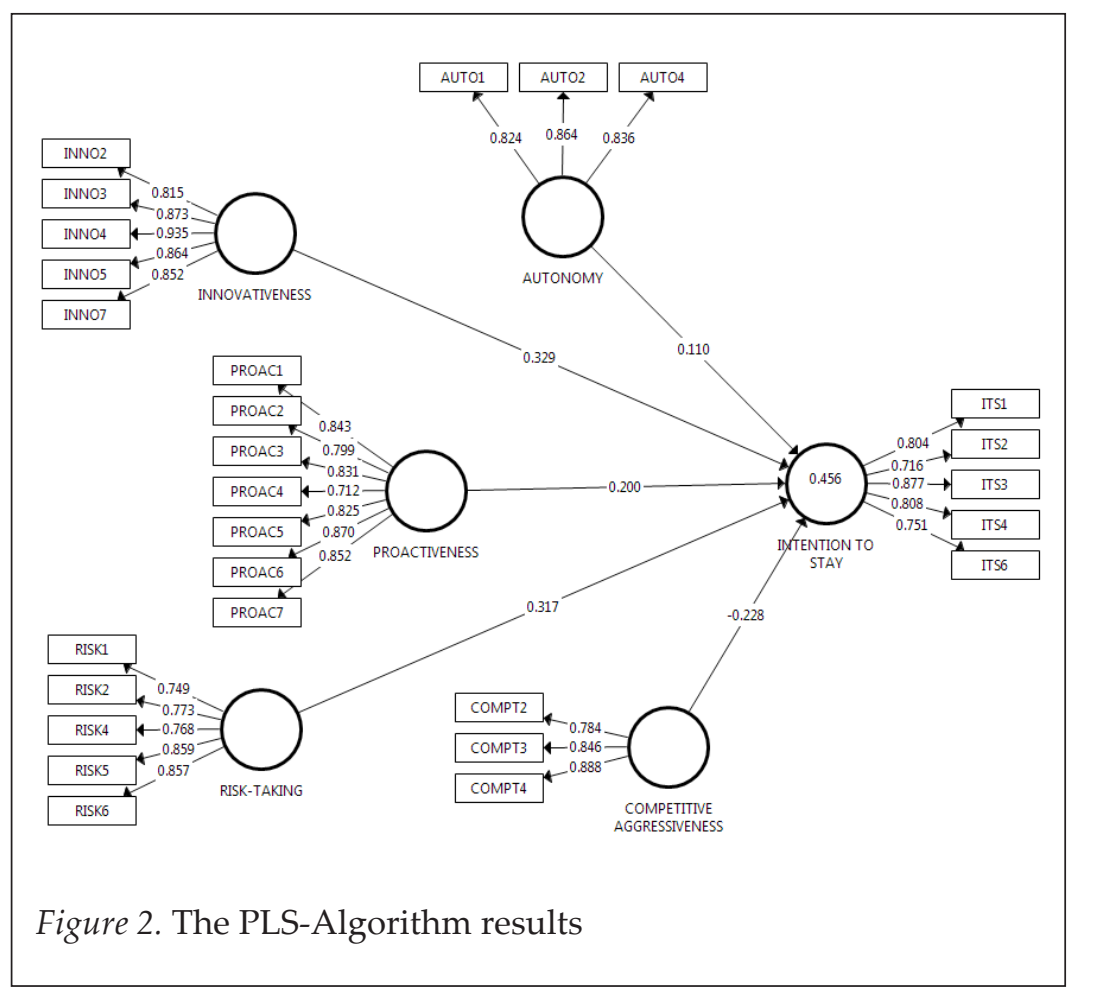

For explanatory power, the LVs (e.g. innovativeness, proactiveness, risk-taking, autonomy and competitive aggressiveness) explained 45.6 percent of the variance, with $R^{2}(0.456)$. Next, we measured the effect size $\left(f^{2}\right)$ to witness the impact of the exogenous latent variables for the endogenous latent variables. The formula used for calculating the effect size was $\left(f^{2}=R^{2}\right.$ included $-R^{2}$ excluded / 1- $R^{2}$ included $)$. The guidelines for the effect size were as follows: 0.35-large; 0.15-medium; and 0.02-small (Hair, Hult, Ringle, and Sarsted, 2014). From the path model, the effect size of risk-taking $(f=0.061)$, innovativeness $\left(f^{2}=0.045\right)$, competitive aggressiveness $\left(f^{2}=0.021\right)$ and proactiveness $\left(f^{2}=0.020\right)$ were found to have small effect size on ITS. However, autonomy $\left(f^{2}=0.007\right)$ did not provide at least a small effect size on ITS.

Table 6 presents the mixed results of the path coefficients, observed t-statistics and the significance level of the hypothesized 
relationships between the variables. From the analysis, it was found that innovativeness $(\beta=0.329 ; t=2.222, p<0.05)$ was positively related to ITS. Therefore, hypothesis $H 1$ was supported. Similarly, $H 2$ $(\beta=0.200 ; t=1.688, p<0.05), H 3(\beta=0.317 ; t=2.479, p<0.05)$ and $H 5(\beta=-$ $0.228 ; t=1.851, p<0.05)$ reported that proactiveness, risk-taking and competitive aggressiveness had positive and significant relationships on engineers' ITQ, therefore these three hypotheses were accepted. However, $\mathrm{H} 4$ had to be rejected as the data did not support the influence of autonomy on ITS amongst the engineers $(\beta=0.110$; $t=0.959)$. The predictive relevance of the Stone-Geisser's $\left(Q^{2}\right)$ test of ITS was obtained by the blindfolding procedure, and the value was 0.421 , and it indicated the predictive relevance of the PLS path model. Figure 3 shows the bootstrapping results.

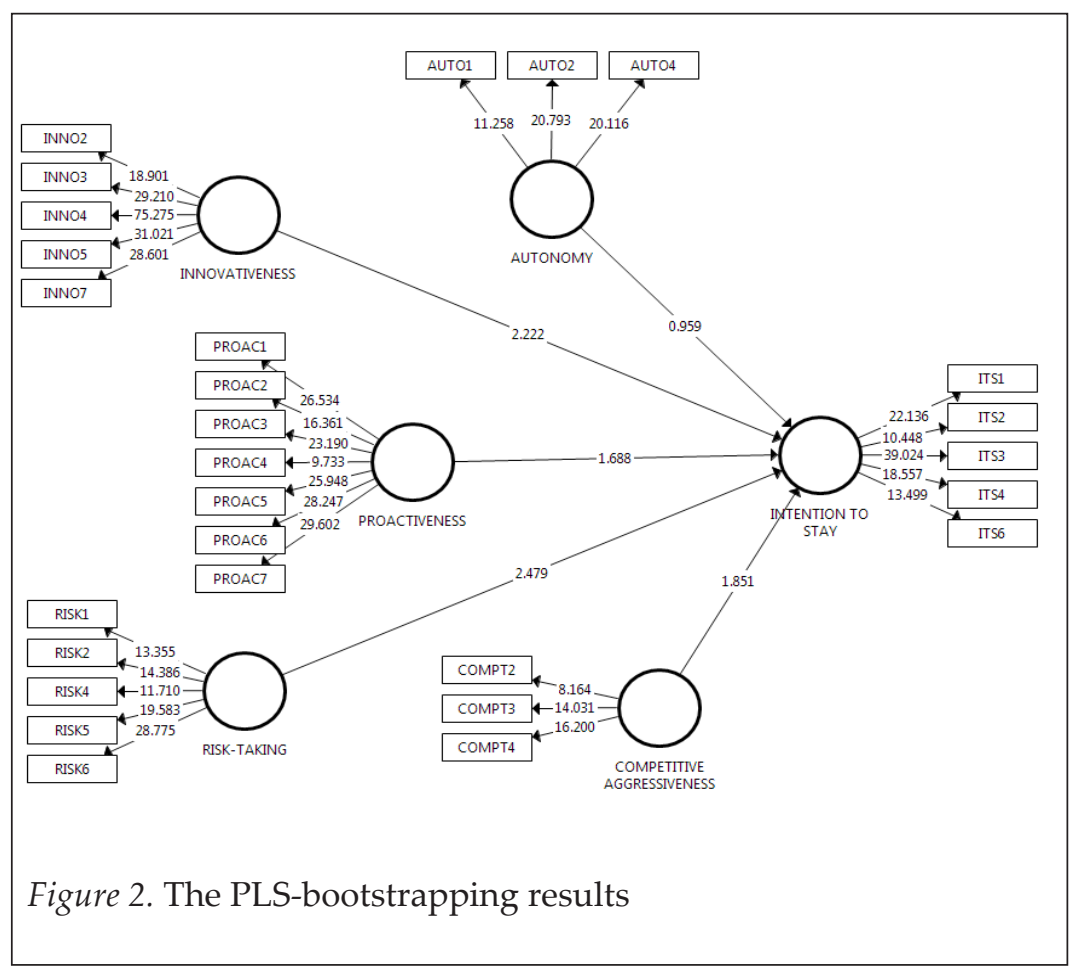


IJMS 25 (1), 105-132 (2018)

Table 6

Results of Path Coefficients and Observed t-statistics

\begin{tabular}{|c|c|c|c|c|}
\hline Hypothesis & Relationships & $\begin{array}{c}\text { Path } \\
\text { coefficient }\end{array}$ & t-value & Results \\
\hline$H 1$ & $\begin{array}{l}\text { Innovativeness } \rightarrow \\
\text { Intention to stay }\end{array}$ & 0.329 & $2.222^{*}$ & Supported \\
\hline H2 & $\begin{array}{l}\text { Proactiveness } \rightarrow \\
\text { Intention to stay }\end{array}$ & 0.200 & $1.688^{*}$ & Supported \\
\hline$H 3$ & $\begin{array}{l}\text { Risk-taking } \rightarrow \\
\text { Intention to stay }\end{array}$ & 0.317 & $2.479 *$ & Supported \\
\hline$H 4$ & $\begin{array}{l}\text { Autonomy } \rightarrow \\
\text { Intention to stay }\end{array}$ & 0.110 & 0.959 & $\begin{array}{c}\text { Not } \\
\text { supported }\end{array}$ \\
\hline H5 & $\begin{array}{l}\text { Competitive } \\
\text { aggressiveness } \rightarrow \\
\text { Intention to stay }\end{array}$ & -0.228 & $1.851^{*}$ & Supported \\
\hline
\end{tabular}

Note. ${ }^{*} p<0.05,{ }^{* *} p<0.01,{ }^{* * *} p<0.001$

\section{Discussion and Conclusion}

The present study was designed to fill the gaps in EO literature and its influence on talent retention amongst engineers in Malaysia. Malaysian engineers' positive behavioural intentions (e.g. ITS) depend on their EO. The positive relationships between EO (e.g. innovativeness, proactiveness, risk-taking and competitive aggressiveness) and ITS have proved the arguments from previous studies (for example, Abdull Rahman, 2012; Bolton et al., 2012; Kollman et al., 2007; Igbaria et al., 1992; Shih et al., 2011). This study concludes that engineers' ITS could be enhanced by practising EO within an organisation. As the EO of an engineer increases, it is probable that his or her ITS will also increase. Engineers with higher innovative behaviours will support exceptional ideas and novelty, and transform them into profitable products. Innovative behaviours support engineers' creativity to design the jobs and tasks to match their specific engineering knowledge and skills, and general competencies. In addition, an engineer with proactive behaviour will act in his or her capacity to anticipate future problems and needs. As an agent of change, engineers see environmental issues as powerful 
demands for upgrading themselves with more skills and experience to work through those changes. An important source to make an engineer bold in his or her performance is his or her readiness to deal with uncertain situations and risks.

Autonomy and ITS, unfortunately, had no significant relationships. This study believes that a considerable amount of autonomy will boost engineers' independent behaviours to resolve engineering taskrelated problems. From an individual's perspective, EO should strive for a high degree of autonomy, emphasising the individual's attitude towards innovation and involving the amount of risk to produce challenges and interesting tasks. Other than that, the individual needs to exploit business opportunities and the need for achievement in his or her career orientations. Bigliardi, Petroni and Dormio (2005); Igbaria et al. (1992) and Kharbanda et al. (1990) have seen engineers' behaviours as unique, unpredictable and full of challenge. Whole phases of the engineer's life cycle within an organisation will be determined by several aspects such as personality, socialisation, technical investment, learning and development and career orientations (Abdull Rahman, 2012; Korte \& Li, 2015; Williamson et al., 2013). Even though engineers' behavioural studies remain scarce, these aspects must be considered to improve the engineers' actual expectations, satisfaction and positive retention outcomes. Unquestionably, by exposing talents (e.g. skills, knowledge, experience), engineers are able to identify flaws, develop solutions and entertain ways to control task-related problems. Several thoughts from early studies (for example, Igbaria et al., 1992 and Kharbanda et al., 1990) argued that matching entrepreneurial characteristics and traits will enhance the entrepreneurial spirit amongst engineers.

The results supply crucial information to organisations as a fundamental means to understand engineers' behaviours and attitudes towards employment. Empirical results have revealed that EO support engineers' intentions to remain in their current jobs and organisations. Unexpected findings were found in engineers' crucial behaviours. For example, engineers' expectations of innovativeness, proactiveness, risk-taking and competitive aggressiveness should be involved in their tasks and responsibilities. Although previous studies have confirmed that EO influences organisational performance (e.g. profit) and growth, none of the available literature provides a link between EBs and talent retention amongst engineers. The pure behaviours of engineers generally relate to a freedom to 
innovate things, face uncertain situations, and expose their creativity to technical knowledge. EO will emphasise the engineers' ability to overcome task-related challenges and act parallel to industrial demands. Moreover, with the emergence of technological, product, and administrative innovation, it has been claimed that many organisations must support engineers' readiness to adopt ideas, and recognise and balance risks. These behaviours expose engineers to new huge career opportunities where talent competitiveness requires engineers to upgrade themselves with new skills and knowledge to compete. Technology, for example, has been a crucial player in the competitive marketplace, and has influenced engineers' awareness about filling in the gaps of having core engineering skills and competencies to support their employment and behavioural expectations.

\section{Implications and Recommendations}

To date, organisations suffer from investing internal cost for recruiting and selecting new talented engineers to replace those who have left, and most probably the new staff may not have acquired the same talents. Cases of engineer migration to other firms have exposed firms to a higher turnover, and employers depend highly on their current experts. The dramatic increase in the need for engineers is linked to technological demands, superior technical knowledge and the major roles in innovation processes (Campbell et al., 2012 and Kharbanda et al., 1990). The current study strongly suggests that management and human resource (HR) managers should focus more on EO in predicting positive behavioural intentions amongst current and future engineers. Regardless of the size of the company, the management must understand EO and its implications in shaping engineers' behavioural expectations. The awareness to attach EO in engineering tasks and jobs must be developed in the first place where engineers can use EO as a job performance reference. Therefore, it is advisable to make it a policy for management and HR managers to link engineers' level of performance with their EO for their career orientations. This, will probably encourage engineering practitioners to design their jobs according to the engineers' abilities to develop and innovate ideas and thoughts, and transform them into tangible results.

A robust theoretical implication from previous studies (for example, Bolton et al., 2012 and Kollman et al., 2007) mentioned that the EO theory 
is a valid construct for measuring an individual's entrepreneurial behaviour within an organisation. This argument is significant why many individual employees (e.g. engineers) rely on their EO for extending their commitment and retention decisions toward the same employment. The researchers in this present study believe that the dominant components of EO (e.g. innovativeness, proactiveness, risktaking, autonomy and competitive aggressiveness) are the primary behaviours for engineers' leading performance and job satisfaction. The effort to match engineers with EO is said to develop engineers as potential intrapreneurs with several characteristics. Amongst them are autonomy, flexibility, adaptability and the capacity to cope with and manage change, self-motivation and drive, analytical ability and decision-making, communication and interpersonal skills, teamworking abilities and skills, organisation, planning and prioritisation abilities, ability to innovate, mental and physical resilience, leadership ability, managing long-term projects, time management, risk-taking, creativity and being an agent of change. Engineer-intrapreneur dual roles impose the power of being a talented individual within an organisation, and are an important source for engineers to be actively involved with many innovation activities for organisational longterm successful entrepreneurial performance.

This study has examined the influence of EO on ITS amongst Malaysian engineers. The findings of this study could be used to help organisations to encourage EO amongst engineers and control their movement to other employers. The talent retention model makes these findings less generalisable to other professional employees. However, this study realises a few potential limitations. Firstly, the sample size for data analysis and interpretation was small. Secondly, the response rate for the study was mainly recruited from limited states in Malaysia. Therefore, it is suggested to increase the number of participants from various nations and industrial businesses. Thirdly, this present study used established items for measuring the EO of engineers within an organisation. There are still other specific but limited items for EO that can be used to measure individual EO. Hence, future research can identify the specific items for measuring the $\mathrm{EO}$ amongst key employees. It is unfortunate that the study did not include other employees and was limited to only the EO, ITS and EO theories. It is recommended that further research should explore, $\mathrm{EO}$ and talent retention in other professions such as accountants, medical doctors, lawyers, lecturers and architects. Further research is suggested to explore and combine the EO theory and other theories (e.g. social cognitive theory and social exchange theory) in predicting 
employee's behavioural intentions, job and career satisfaction. A greater focus on talent retention could produce interesting findings that account for more variables such as teamwork, organisational citizenship behaviour, leader-member exchange, trust and organisational support.

\section{References}

Abdull Rahman, R. H. (2012). Malaysian firms' role in retaining engineers. The Economic and Labour Relations Review, 23(4), 5778.

Alavi, S. B., Moteabbed, \& S. Arasti, M. R. (2012). A qualitative investigation of career orientations of a sample of Iranian software engineers. Scientia Iranica, 19(3), 662-673.

Antoncic, J. A., \& Antoncic, B. (2011). Employee satisfaction, intrapreneurship and firm growth: A model. Industrial Management \& Data Systems, 111(4), 589-607.

Avanzi, L., Fraccaroli, F., \& G. Sarchielli, J. Ullrich, R. V. Dick, (2014). Staying or leaving: A combined social identity and social exchange approach to predicting employee turnover intentions. International Journal of Productivity and Performance Management, 63(3), 272-28.

Bigliardi, B., Petroni, A., \& Dormio, A. I. (2012). Organizational socialization, career aspirations and turnover intentions among design engineers. Leadership \& Organization Development Journal, 26(6), 424-441.

Bolton, D. L., \& Lane, M. D. (2012). Individual entrepreneurial orientation: Development of a measurement instrument. Education and Training, 54(2/3), 219-233.

Campbell, R. I., Gluesing, J., \& Perelli, S. (2012). Mindfulness and product failure management: An engineering epistemology. International Journal of Quality \& Reliability Management, 29(6), 642-665.

Chang, C. P., \& Chang, W. C. (2008). Internal marketing practices and employees' turnover intentions in tourism and leisure hotels. The Journal of Human Resource and Adult Learning, 4(2), 161-172.

Collings, D. G., \& Mellahi, K. (2009). Strategic talent management: A review and research agenda. Human Resource Management Review, 19(4), 304-313.

Covin, J. G., \& Slevin, D. P. (1986). The development and testing of an organizational-level entrepreneurship scale. In Ronstadt, R. et al. (Eds.), Frontiers of Entrepreneurship Research, babson college, Wellesley, MA, 628-39. 
Crant, J. M. (2000). Proactive behaviour in organizations. Journal of Management, 26(3), 435-462.

Davis, J. L., Bell, R. G., Payne, G. T., \& Kreiser, P. M. (2010). Entrepreneurial orientation and firm performance: The moderating role of managerial power. American Journal of Business, 25(2), 41-54.

Dries, N. (2013). The psychology of talent management: A review and research agenda. Human Resource Management Review, 23, 272285.

Elenurm, T. (2012). Entrepreneurial orientations of business students and entrepreneurs. Baltic Journal of Management, 7(2), 217-231.

Entebang, H., Harrison, R. T., \& Run, E. C. (2010). Entrepreneurial orientation of public enterprises in Malaysia. Business Strategy Series, 11(2), 75-77.

Festing, M., \& Scha"fer, L. (2014). Generational challenges to talent management: A framework for talent retention based on the psychological-contract perspective. Journal of World Business, 49, 262-271.

Gangrade, D., Dubey, S., \& Chouhan, O. (2014). Talent retention: Winning competitive edge (a study in academic sector). Envision a Monthly Referred Journal of Management and IT, 1(1).

Gelens, J., Dries, N., Hofmans, J., \& Pepermans, R. (2013). The role of perceived organizational justice in shaping the outcomes of talent management: A research agenda. Human Resource Management Review, 23, 341-353.

George, C. Retaining professional workers: What makes them stay? Employee Relations, 37(1), 102-121.

Govaerts, N., Kyndt, E., Dochy, F., \& Baert, H. (2011). Influence of learning and working climate on the retention of talented employees. Journal of Workplace Learning, 23(1), 35-55.

Griffin, M. A., Neal, A., \& Parker, S. K. (2007). A new model of work role performance: Positive behavior in uncertain and interdependent constructs. Academy of Management Journal, 50(2), 327-347.

Grip, A. D., \& Smits, W. (2012). What affects lifelong learning of scientists and engineers? International Journal of Manpower, 33(5), 583-597.

Guidice, R. M., Heames, J. T., \& Wang, S. (2009). The indirect relationship between organizational-level knowledge worker turnover and innovation. The Learning Organization, 16(2), 143167.

Hair, J. F., Hult, G. T. M., Ringle, C. M., \& Sarsstedt, M. (2014). A primer on partial least squares structural equation modelling (PLSSEM). California: SAGE Publication, Inc. 
Hashim, R., \& Wok, S. (2015). Levels of engineers' participative decision-making in Tenaga Nasional Berhad. Asian Social Science, 11(17), 130-135.

Hiltrop, J. M. (1999). The quest for the best: Human resource practices to attract and retain talent. European Management Journal, 17(4), 422-430.

Igbaria, M., \& Siegel, S. R. (1992). An examination of the antecedents of turnover propensity of engineers: An integrated model. Journal of Engineering and Technology Management, 9, 101-126.

Igbaria, M., Kassicieh, S. K., \& Silver, M. (1999). Career orientations and career success among research, and development and engineering professionals. Journal of Engineering Technology Management 16, 29-54.

Jia, J., Wang, G., \&Yu, X.Z.X.(2014). Exploring the relationship between entrepreneurial orientation and corporate performance. Nankai Business Review International, 5(3), 326-344.

Khalili, H., Nejadhussein, S., \& Fazel, A. (2013). The influence of entrepreneurial orientation on innovative performance. Journal of Knowledge-based Innovation in China, 5(3), 262-278.

Kharbanda, O. P., \& Stallworthy, E. A. (1990). Management for engineers. International Journal of Operations and Production Management, 10(6), 2-91.

Kollman, T., Christofor, J., \& Kuckertz, A. (2007). Explaining individual entrepreneurial orientation: Conceptualisation of a cross-cultural research framework. International Journal of Entrepreneurship and Small Business, 4(3), 25-340.

Korte, R., \& Li, J. (2015). Exploring the organizational socialization of engineers in Taiwan. Journal of Chinese Human Resource Management, 6(1), 33-51.

Krishnakumar, S., Devi, S. P., \& Rao, K. S. P. (2013). A business dynamics model in entrepreneurial orientation for employees. Industrial and Commercial Training, 45(1), 36-50.

Kropp, F., Lindsay, N. J., \& Shoham, A. (2006). Entrepreneurial, market, and learning orientations and international entrepreneurial business venture performance in South African firms. International Marketing Review, 23(5), 504-523.

Lee, D. M. S. (1994). Social ties, task-related communication and first job performance of young engineers. Journal Engineering Technology Management I1, 203-228.

Lewis, R. E., \& Heckman, R. J. (2006). Talent management: A critical review. Human Resource Management Review, 16, 139-154.

Lumpkin, G. T., \& Dess, G. G. (1996). Clarifying the entrepreneurial orientation construct and linking it to performance. Academy of Management Review, 21(1), 135-172. 
Menzel, H. C., Aaltio, I., \& Ulijn, M. (2007). On the way to creativity: Engineers as intrapreneurs in organizations. Technovation, 27, 732-743.

Oyedele, L. O. (2010). Sustaining architects' and engineers' motivation in design firms: An investigation of critical success factors. Engineering, Construction and Architectural Management, 17(2), 180-196.

Price, J. L., \& Mueller, C. W. (1981). A causal model of turnover for nurses. Academy of Management Journal, 24, 543-565.

Rauch, A., Wiklund, J., Lumpkin, G. T., \& Frese, M. (2009). Entrepreneurship orientation and business performance: An assessment of past research and suggestions for the future. Entrepreneurship Theory \& Practice, 33(3), 518-528.

Sahi, G. K., \& Mahajan, R. (2014). Employees' organisational commitment and its impact on their actual turnover behaviour through behavioural intentions. Asia Pacific Journal of Marketing and Logistics, 26(4), 621-646.

Shih, A. S., \& Susanto, E. (2011). Is innovative behavior really good for the firm? Innovative work behavior, conflict with coworkers and turnover intention: Moderating roles of perceived distributive fairness. International Journal of Conflict Management, 22(2), 111-130.

Taatila, V., \& Down, S. (2012). Measuring entrepreneurial orientation of university students. Education and Training, 54(8/9), 744-760.

Tansley, C. (2011). What do we mean by the term "talent" in talent management? Industrial and Commercial Training, 43(5), 266-274.

Tett, R. P., \& Meyer, J. P. (1993). Job satisfaction, organizational commitment, turnover intention, and turnover: Path analysis based on meta-analytic findings. Personnel Psychology, 46(2), 342-346.

Tremblay, M., Wils, T., \& Proulx, C. (2002). Determinants of career path preferences among Canadian engineers. Journal of Engineering Technology Management, 19, 1-23.

Udo, J., Guimãrães, T., \& Igbaria, M. (1997). An investigation of the antecedents of turnover intention for manufacturing plant managers. International Journal of Operations $\mathcal{E}$ Production Management, 17(9), 912-930.

Williamson, J. M., Lounsbury, J. W., \& Han, L. D. (2013). Key personality traits of engineers for innovation and technology development. Journal of Engineering Technology Management, 30, 157-168. 
IJMS 25 (1), 105-132 (2018)

$\mathrm{Wu}, \mathrm{J}$. (2009). Entrepreneurial orientation, entrepreneurial intent and new venture creation: Test of a framework in a Chinese context (Unpublished Doctoral Thesis). Virginia Polytechnic Institute and State University.

Yang, C., Ma, Q., \& Hu, L. (2011). Job embeddedness: A new perspective to predict voluntary turnover. Nankai Business Review International, 2(4), 418-446.

Yi, C. P. Sheu, \& Zhi, H. (2009, November). A research review on entrepreneurial and intrapreneurial characteristics. The 9th International Conference on Electronic Business, Macau.

Zhang, S., \& Bright, D. (2012). Talent definition and talent management recognition in Chinese private-owned enterprises. Journal of Chinese Entrepreneurship, 4(2), 143-163. 